\title{
PROFIL PEMAHAMAN KONSEP MATEMATIKA DITINJAU DARI GAYA KOGNITIF FIELD INDEPENDENT (FI) DAN FIELD DEPENDENT (FD)
}

\author{
Ni Hayah ${ }^{1)}$, Bakri Mallo ${ }^{2)}$, I Nyoman Murdiana ${ }^{3)}$ \\ nihayanhia@gmail.com ${ }^{1)}$,bakri06@yahoo.co.id ${ }^{2)}$,nyomanperdos@gmail.com ${ }^{3)}$
}

\begin{abstract}
abstrak: Penelitian ini bertujuan untuk mendeskripsikan pemahaman konsep matematika siswa kelas XI SMA Negeri 2 Dampelas dalam menyelesaikan soal pada subpokok bahasan parabola ditinjau dari gaya kognitif Field Independent (FI) dan Field Dependent (FD). Jenis penelitian ini adalah penelitian kualitatif. Subjek dalam penelitian ini terdiri dari satu siswa yang bergaya kognitif FI dan satu siswa yang bergaya kognitif FD. Hasil dari penelitian ini yaitu saat menyajikan masalah, subjek FI dan FD menuliskan hal-hal yang diketahui dan ditanyakan. Selanjutnya dalam mengklasifikasi unsur-unsur parabola, subjek FI mengelompokkan unsur-unsur parabola menurut bentuk parabolanya yaitu parabola horizontal terbuka ke kanan. Kemudian dalam memberi contoh dan non-contoh pada setiap unsur-unsur parabola, subjek FI memberikan contoh dan non-contoh dari setiap unsurunsur parabola yang diberikan. Kemudian menyajikan masalah persamaan parabola dalam representasi matematis, subjek FI dan subjek FD menyajikan persamaan parabola kedalam bentuk persamaan umum parabola. Kemudian menggunakan, memanfaatkan dan memilih prosedur tertentu dalam menentukan persamaan parabola, subjek FI menggunakan dan memilih persamaan umum parabola horizontal dan subjek FD menggunakan persamaan umum parabola walaupun subjek tidak mengetahui jenis persamaan umum parabola yang digunakan. Kemudian subjek FI menjelaskan kembali prosedur yang digunakan serta memberikan alasannya dengan menggunakan bahasanya sendiri dan subjek FD menjelaskan kembali prosedur yang digunakan walaupun dalam proses penyelesaiannya siswa belum memahami dengan baik langkah-langkah yang harus digunakan.
\end{abstract}

Kata Kunci: Profil; Pemahaman konsep matematika; Parabola;

abstract: This study aims to describe the understanding of mathematical concepts of class XI students of SMA 2 Dampelas in solving problems on the subject of the parabolic discussion reviewed from cognitive style of the Independent Field (FI) and Field Dependent (FD). This type of research is qualitative research. The subjects in this study consisted of one student who was in the cognitive style of FI and one student in the cognitive style of FD. The results of this study are when presenting a problem, FI and FD subject write things that are known and asked. Furthermore, in classifying parabolic elements, FI subjects classify parabolic elements according to their parabolic forms, namely horizontal parabola open to the right. Then in giving examples and non-examples of each parabolic element, the FI subject gives examples and non-examples of each parabolic element given. Then presenting the problem of parabolic equations in mathematical representations, the subject FI and subject FD present the parabolic equation in the form of a general parabolic equation. Then using, utilizing and selecting a particular procedure in determining the parabolic equation, FI subject uses and selects the general horizontal parabolic equation and the FD subject uses the general parabolic equation even though the subject does not know the type of general parabolic equation used. Then the FI subject explains the procedure used again and gives the reason using its own language and the FD subject explains the procedure used even though in the process of completion students do not understand the steps that must be used properly.

Keywords: Profile; Understanding of mathematical concepts; Parabolic;

Matematika merupakan ilmu dasar dari segala ilmu pengetahuan yang perlu untuk diketahui dan dipelajari. Oleh karena itu matematika mulai dikenalkan sejak pendidikan anak usia dini, pendidikan dasar, pendidikan menengah hingga perguruan tinggi. Akan tetapi sebagian besar peserta didik beranggapan bahwa belajar matematika itu hanya dengan 
menghafal rumus lalu menyelesaikan soal dengan rumus yang sudah dihafal melalui operasi hitung dengan bilangan atau angka, huruf, dan simbol saja. Mereka beranggapan bahwa belajar matematika tidak perlu adanya kebermaknaan dan pemahaman konsep. Nurfarikhin (2010) menyebutkan bahwa semua materi matematika yang ada di sekolah mengandung aspek pemahaman konsep karena memang kemampuan mendasar dalam belajar matematika adalah memahami konsep terlebih dahulu. Pemahaman adalah kemampuan atau proses berpikir untuk menangkap makna dari suatu hal serta dapat menafsirkan melalui bahasa sendiri berdasarkan konsep matematika. Dalam mempelajari matematika, pemahaman konsep matematika sangat penting untuk siswa, karena konsep matematika yang satu dengan yang lainnya berkaitan sehingga untuk mempelajarinya harus runtut dan berkesinambungan. Jika siswa telah memahami konsep-konsep matematika maka akan memudahkan siswa dalam mempelajari konsep-konsep matematika berikutnya. Hal ini sejalan dengan pernyataan Utari (2012) yang menyatakan bahwa dengan memahami konsep, siswa dapat mengembangkan kemampuannya dalam pembelajaran matematika, siswa dapat menerapkan konsep yang telah dipelajarinya untuk menyelesaikan permasalahan sederhana sampai dengan yang kompleks.

Irisan kerucut merupakan satu diantara materi pada matematika peminatan yang diajarkan di sekolah menengah atas tepatnya pada kelas XI. Satu diantara kompetensi pembelajaran pada matematika peminatan dalam Permendikbud no.64 tahun 2013 yaitu memahami persamaan berbagai irisan kerucut serta grafiknya dan kaitannya. Namun kenyataannya masih banyak siswa yang pada umumnya belum memahami konsep matematika sehingga mengalami kesulitan dalam mempelajari materi irisan kerucut seperti menyelesaikan soal persamaan parabola. Satu diantara penyebab yang menimbulkan kesulitan siswa dalam mengerjakan soal-soal matematika dan menimbulkan jawaban siswa yang bervariasi ialah tingkat pemahaman konsep matematika. Hal ini sejalan dengan pernyataan dari Kumalasari (2013) yang menyatakan bahwa siswa yang mengalami kesulitan dalam mempelajari matematika pada umumnya terletak pada kurangnya pemahaman konsep dan prinsip dalam matematika.

Berdasarkan hasil dialog dengan guru matematika peminatan kelas XI di SMA Negeri 2 Dampelas, diperoleh informasi bahwa beberapa siswa hanya menghafal rumus yang ada dalam materi parabola tanpa memahami makna dari rumus tersebut. Ketika siswa diberikan soal mengenai parabola, ada beberapa siswa tidak dapat menyelesaikan soal tersebut dengan benar dan tepat sehingga jawaban siswa berbeda-beda antara siswa satu dan siswa lainnya. Hal tersebut menunjukkan masih rendahnya pemahaman konsep matematika siswa yang menyebabkan siswa belum dapat menyelesaikan soal irisan kerucut khususnya parabola dengan tepat. Hasil penelitian yang telah dilakukan oleh Darojah (2018) bahwa berdasarkan hasil wawancara peneliti dengan siswa, diperoleh data bahwa siswa kurang memahami konsep mengenai irisan kerucut. Hal ini dapat dilihat pula melalui data observasi, ketika siswa diberi tugas oleh guru untuk mencari persamaan irisan kerucut yang berbeda titik pusatnya, sebagian besar siswa masih bingung. Sejalan dengan hasil penelitian yang telah dilakukan oleh Sari (2015) bahwa siswa merasa kesulitan memahami materi irisan kerucut karena penguasaan konsep lemah dan pada kondisi lapangan, siswa hanya melihat rumus-rumus irisan kerucut sebatas sesuatu yang harus dihafalkan.

Kemampuan pemahaman konsep siswa dipengaruhi oleh beberapa faktor. Faktor tersebut muncul karena setiap siswa memiliki perbedaan-perbedaan. Salah satu faktor yang mempengaruhi pemahaman konsep siswa yaitu gaya kognitif. Pada pembelajaran matematika, perlu diperhatikan gaya kognitif siswa. Gaya kognitif adalah karakteristik seseorang dalam mengumpulkan informasi, menyimpan dan mengolah informasi serta 
membuat keputusan untuk menanggapi suatu masalah dalam kegiatan belajar. Devi (2018) mengemukakan bahwa, gaya kognitif siswa juga menjadi faktor yang turut mempengaruhi pemahaman konsep matematis siswa. Witkin dkk (1975) mengemukakan bahwa gaya kognitif terdiri atas dua yaitu gaya kognitif Field Independent (FI) dan gaya kognitif Field Dependent (FD). Gaya kognitif Field Independent (FI) adalah cara-cara khas yang digunakan siswa dalam kegiatan belajar yang berkaitan dengan mengumpulkan informasi, memproses informasi dan membuat keputusan yang tidak dipengaruhi oleh lingkungan dan tidak bergantung pada lingkungan. Gaya kognitif Field Dependent (FD) adalah cara-cara khas siswa dalam mengumpulkan informasi, memproses informasi dan membuat keputusan dalam kegiatan belajar yang dipengaruhi oleh lingkungan dan bergantung pada lingkungan.

Dalam rangka mendapatkan informasi yang lebih akurat mengenai pemahaman konsep matematika yang ditinjau dari gaya kognitif siswa, maka pemahaman konsep matematika ditinjau dari gaya kognitif siswa perlu diprofilkan atau digambarkan dalam bentuk deskriptif, kata-kata dan tulisan secara mendalam agar pemahaman konsep matematika siswa lebih diketahui berdasarkan gaya kognitifnya. Satu diantara upaya guru dapat mengatasi kesulitan yang dialami siswa yakni dengan mengetahui gambaran pemahaman konsep matematika yang ditinjau dari gaya kognitif siswa. Menurut Suryosubroto (2009:21) bahwa pada hakikatnya bila suatu kegiatan direncanakan lebih dahulu maka tujuan dari kegiatan tersebut akan lebih terarah dan berhasil. Itulah sebabnya seorang guru harus memiliki kemampuan dalam merencanakan pengajaran. Gambaran mengenai pemahaman konsep matematika ditinjau dari gaya kognitif seseorang inilah dinamakan profil pemahaman konsep matematika ditinjau dari gaya kognitif.

Berdasarkan uraian pada latar belakang, maka rumusan masalah dalam penelitian ini, yaitu bagaimana profil pemahaman konsep matematika siswa kelas XI SMA Negeri 2 Dampelas dalam menyelesaikan soal pada subpokok bahasan parabola dengan gaya kognitif Field Independent (FI) dan Field Dependent (FD)?

\section{METODE PENELITIAN}

Jenis penelitian ini adalah penelitian kualitatif dengan pendekatan deskriptif kualitatif yaitu mendeskripsikan profil pemahaman konsep matematika siswa yang bergaya kognitif FI dan FD. Subjek dalam penelitian ini ialah siswa kelas XI MIA SMA Negeri 2 Dampelas dengan jumlah keseluruhan 25 siswa. Kemudian subjek penelitian diambil masing-masing satu siswa yang memiliki gaya kognitif FI yaitu WS dan satu siswa yang memiliki gaya kognitif FD yaitu DN.

Jenis data yang digunakan dalam penelitian ini adalah data kualitatif berupa data tentang profil pemahaman konsep matematika siswa kelas XI SMA Negeri 2 Dampelas dalam menyelesaikan soal pada subpokok bahasan parabola ditinjau dari gaya kognitif FI dan FD berdasarkan indikator pemahaman konsep matematika yang digunakan. Teknik pengumpulan data pada penelitian ini adalah tes dan wawancara. Instrumen penelitian terdiri atas instrumen utama, yaitu peneliti sendiri dan instrumen pendukung yaitu GEFT dan tes tertulis yang berisi masalah parabola yang terdiri dari empat soal yaitu M1: 1) Diketahui persamaan parabola $y^{2}-8 x-4 y-4=0$. a. Tentukanlah unsur-unsur parabola yaitu titik puncak, titik fokus, garis direktris, sumbu simetri dan panjang latus rectum. b. Gambarlah grafiknya. 2) Tentukanlah persamaan parabola dengan sumbu simetri sejajar $x=0$ dan melalui titik-titik $(-2,4),(-3,2)$ dan $(-11,-2)$. M2: 1) Diketahui persamaan parabola $y^{2}-8 x-6 y+1=0$. a. Tentukanlah unsur-unsur parabola yaitu titik puncak, titik fokus, garis direktris, sumbu simetri dan panjang latus rectum. b. Gambarlah grafiknya. 
2) Tentukanlah persamaan parabola dengan sumbu simetri sejajar $x=0$ dan melalui titiktitik $(-2,2),(-5,4)$ dan $(-13,-4)$.

Analisis data dilakukan dengan mengacu pada analisis data kualitatif model Miles dan Huberman (Sugiyono, 2015) yaitu: kondensasi data (Data Condensation), penyajian data (Data Display) dan kesimpulan/verifikasi (conclusion/Verification). Pengujian kredibilitas data yang digunakan pada penelitian ini adalah triangulasi waktu, yaitu teknik pengujian kredibilitas data dengan cara memperoleh data dari sumber yang sama dengan masalah yang setara dalam waktu yang berbeda.

\section{HASIL PENELITIAN}

Hasil pengelompokkan siswa yaitu 7 siswa dengan gaya kognitif FI dan 18 siswa dengan gaya kognititf FD. Setiap gaya kognitif dipilih masing-masing satu siswa sebagai subjek dari gaya kognitif. Uji kredibilitas data dilakukan dengan menggunakan tringulasi waktu dengan memberikan dua masalah yang setara pada waktu yang berbeda yaitu M1 dan M2. Kedua masalah tersebut telah kredibel. Data yang dianalisis dalam penelitian ini adalah tentang profil pemahaman konsep siswa berdasarkan indikator pemahaman konsep dalam menyelesaikan M2.

\section{Pemahaman konsep matematika siswa yang bergaya kognitif FI (WS) dalam menyelesaikan soal pada subpokok bahasan parabola}

Pemahaman konsep WS dalam mengklasifikasikan unsur-unsur parabola dan menyajikan masalah kedalam berbagai bentuk representasi matematis M2, dipaparkan sebagaimana Gambar 1 dan 2:

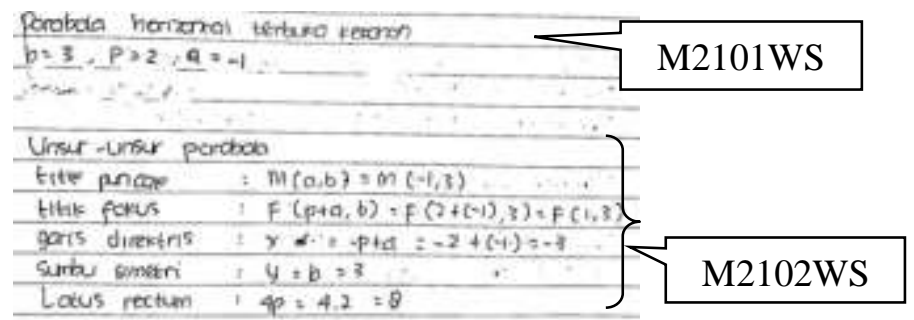

Gambar 1

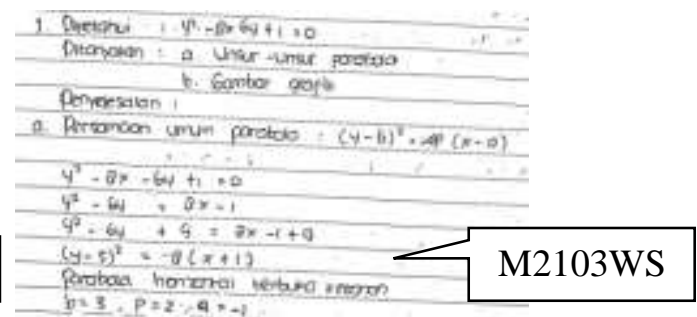

Gambar 2.

Berdasarkan Gambar 1, WS mengelompokkan unsur-unsur parabola (M2102WS) berdasarkan jenis parabolanya yaitu parabola horizontal terbuka ke kanan (M201WS), sehingga dapat dikatakan bahwa WS mengklasifikasikan unsur-unsur parabola berdasarkan sifat-sifat pada jenis parabolanya. Selanjutnya peneliti melakukan wawancara dengan WS untuk memperoleh informasi lebih lanjut tentang pemahaman konsep WS dalam mengklasifikasi unsur-unsur parabola sebagaimana transkrip berikut:

PNM21013 : Kenapa kamu tulis ini, parabolanya horizontal terbuka ke kanan?

WSM21014 : Karena y-nya yang dipangkatkan dan saya dapatkan p-nya positif.

PNM21021 : Terus, apalagi itu di bawahnya?

WSM21022 : Titik fokusnya $\mathrm{F}(\mathrm{p}+\mathrm{a}, \mathrm{b})$ sama dengan $(2+(-1), 3)=\mathrm{F}(1,3)$

PNM21023 : Kenapa bisa titik fokusmu F(p+a,b)?

WSM21024 : Karena parabolanya horizontal terbuka ke kanan

PNM21027 : Terus, di bawahnya apalagi itu?

WSM21028 : Garis direktrisnya $\mathrm{x}=-\mathrm{p}+\mathrm{a}=-2+(-1)=-3$, sumbu simetrinya $\mathrm{y}=-2$, dan latus rektumnya $4 \mathrm{p}=4$ dikali $2=8$. 
PNM21029 : Kenapa ini juga bisa garis direktrismu $\mathrm{x}=-\mathrm{p}+\mathrm{a}=-2+(-1)=-3$, sumbu simetrinya $\mathrm{y}=$ -2 . Dan latus rektumnya $4 \mathrm{p}=4$ dikali $2=8$ ?

WSM21030 : Karena parabolanya dia terbuka ke kanan.

Hasil wawancara menunjukkan bahwa WS mengklasifikasikan unsur-unsur parabola menurut sifat-sifat pada jenis parabolanya (WSM21014, WSM21024 dan WSM21030) sehingga WS dapat menemukan nilai pada setiap unsur-unsur parabola (WSM21022 dan WSM21028), sehingga dapat dikatakan bahwa WS mengklasifikasikan unsur-unsur parabola secara lisan dalam memahami masalah.

Peneliti melakukan wawancara dengan WS untuk memperoleh informasi tentang kemampuan pemahaman WS dalam memberi contoh pada setiap unsur parabola dan non contoh dari unsur-unsur parabola sebagaimana transkrip berikut:

PNM21033 : Ini dek. Kalau dari gambar grafik parabola ini, yang ini apanya? (sambil menunjuk sumbu simetri).

WSM21034 : Sumbu simetri ka.

PNM21035 : Kalau sumbu simetrinya ini begini, kenapa? (sambil menunjuk non-contoh garis sumbu simetri)

WSM21036 : Bukan sumbu simetri namanya kak.

PNM21037 : Yang bagaimana itu sumbu simetrikah?

WSM21038 : Sumbu simetri itu dia harus melalui titik fokus dan titik puncaknya parabola kak.

PNM21039 : Kalau ini, apa namanya? (sambil menunjuk titik fokus)

WSM21040 : Titik fokus kak.

PNM21041 : Kalau disini titik fokusnya, kenapa? (sambil menunjuk titik yang bukan titik fokus)

WSM21042 : Bukan titik fokus itu kak, titik fokus harus disini kak, dibagian sini.

PNM21043 : Bagian apa itu dek?

WSM21044 : Bagian dalam parabola kak.

PNM21045 : Kalau ini apanya? (sambil menunjuk garis latus rectum)

WSM21046 : Latus rectumnya

PNM21047 : Kalau disini latus rectumnya, kenapa? (sambil menunjuk garis yang bukan garis latus rectum)

WSM21048 : Tidak bisa kak, latus rectumnya harus disini, melalui titik fokusnya parabola.

PNM21049 : Kalau ini apanya? ( sambil menunjuk titik puncak)

WSM21050 : Titik puncaknya.

PNM21051 : Apakah bisa kalau titik puncaknya disini? (sambil menunjuk titik yang bukan titik puncak).

WSM21052 : Tidak bisa kak, dia harus di sini.

PNM21053 : Kenapa tidak bisa?

WSM21054 : Karena namanya kan puncak, jadi dia betul-betul harus diujung.

PNM21055 : Kalau ini apanya ? (sambil menunjuk garis direktris)

WSM21056 : Garis direktrisnya kak.

PNM21057 : Kalau disini, kenapa? (sambil menunjuk garis yang bukan garis direktris)

WSM21058 : Bukan garis direktris itu kak, tapi garis miring.

PNM21059 : Kenapa bukan garis direktris?

WSM21060 : Garis direktris ini harus sejajar dengan sumbu-x. 
Hasil wawancara menunjukkan bahwa WS dapat memberikan contoh dan bukan contoh dari setiap unsur-unsur parabola yaitu sumbu simetri, titik fokus, latus rectum, garis direktris dan titik puncak disertai dengan alasan mengenai aturan tempat kedudukan setiap unsur-unsur pada gambar grafik parabola, sehingga dapat dikatakan bahwa WS mampu memberi contoh dari setiap unsur-unsur parabola dan non-contoh dari setiap unsur-unsur parabola.

Setelah memberi contoh dan non-contoh, selanjutnya WS menyajikan suatu masalah persamaan parabola dalam berbagai bentuk representasi matematis sebagaimana Gambar 2 . Berdasarkan Gambar 2, WS menyajikan masalah kedalam berbagai bentuk representasi matematis diantaranya yaitu menyajikan persamaan parabola yang diketahui kedalam bentuk persamaan umum parabola (M2103WS), sehingga dapat dikatakan bahwa WS mampu menyajikan masalah kedalam berbagai bentuk representasi matematis.

Peneliti melakukan wawancara dengan WS untuk memperoleh informasi lebih lanjut tentang pemahaman konsep matematika WS dalam menyajikan masalah kedalam berbagai bentuk representasi matematis sebagaimana transkrip berikut:

PNM21003 : Terus, setelah itu bagaimana cara penyelesaianmu?

WSM21004 : Persamaan $y^{2}-8 x-6 y+1=0$ saya buat modelnya seperti ini ke persamaan umumnya ini $(y-b)^{2}=4 p(x-a)$.

PNM21005 : Kenapa kamu buat modelnya begitu?

WSM21006 : Kan persamaan ini persamaan parabola yang bukan titik puncaknya $(0,0)$ dilihat dari sini, kan yang berpangkat dua $y$, terus ada $y$ yang berpangkat satu. Jadi saya buat modelnya seperti persamaan umum $(y-b)^{2}=4 p(x-a)$ supaya dari persamaan ini saya dapat nilai, $a, b$, sama $p$-nya yang dipakai di unsur-unsur parabolanya.

PNM21015 : Terus, kenapa $\mathrm{a}=-1, \mathrm{~b}=3$ dan $\mathrm{p}=2$ ?

WSM21016 : Dari persamaan ini (menunjuk persamaan yang telah didapatkan). Kan persamaaan $y^{2}-8 x-6 y+1=0$ sudah saya buat seperti persamaan umum.

Hasil wawancara menunjukkan bahwa WS menjelaskan alasan mengapa menyajikan masalah kedalam bentuk persamaan umum $(y-b)^{2}=4 p(x-a)$ yaitu (WSM21006) dan (WSM21016), sehingga dapat dikatakan bahwa WS mampu memberikan alasan dan menyajikan masalah kedalam berbagai bentuk representasi matematis.

Kemudian WS dalam menggunakan, memanfaatkan dan memilih prosedur tertentu dalam menentukan persamaan parabola sebagaimana Gambar 3:

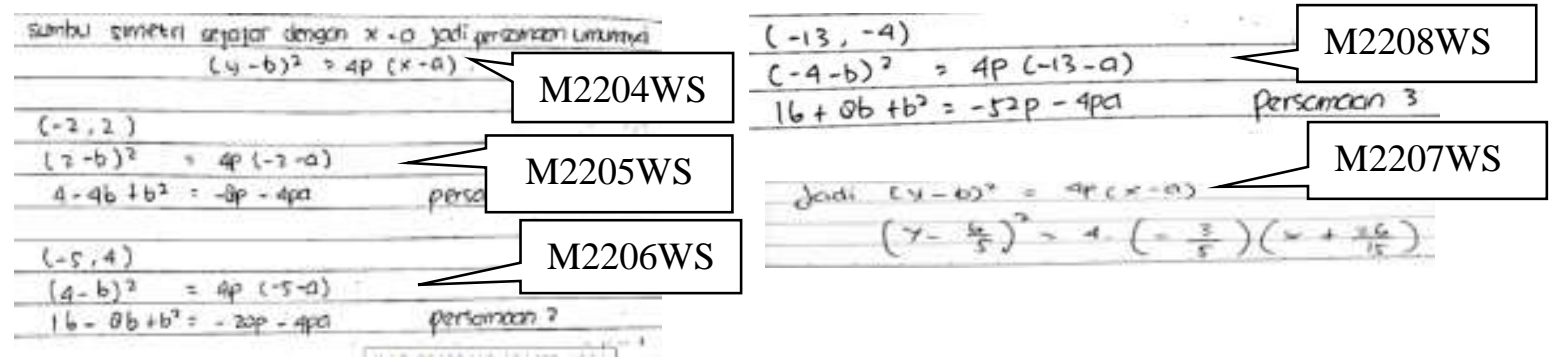

Gambar 3. Jawaban Subjek WS Menggunakan, Mamanfaatkan dan Memilih Prosedur Tertentu dalam Menentukan Persamaan Parabola M2

Berdasarkan Gambar 3, WS menggunakan, memanfaatkan dan memilih prosedur tertentu yaitu persamaan umum parabola horizontal (M2204WS) dalam menentukan persamaan parabola dari titik-titik yang diketahui yaitu (M2205WS), (M2206WS), 
(M2207WS) dan menggunakan persamaan tersebut untuk mendapat hasil akhirnya yaitu (M2208WS) sehingga dapat dikatakan bahwa WS mampu menggunakan, memanfaatkan dan memilih prosedur tertentu dalam menentukan persamaan parabola.

Peneliti melakukan wawancara dengan WS untuk memperoleh informasi tentang kemampuan pemahaman konsep matematika WS dalam menggunakan, memanfaatkan dan memilih prodesur tertentu dalam menentukan persamaan parabola, sebagaimana transkrip berikut:

PNM22063 : Nah, bagaimana kamu menyelesaikannya?

WSM22064 : Persamaan umumnya $(y-b)^{2}=4 p(x-a)$, jadi ketiga titiknya ini saya subtitusikan satu-satu ke persamaan umum. Pertama titik $(-2,2)$ ini dulu saya subtitusikan kepersamaan umumnya ini. Dan saya dapat hasilnya persamaan 1 , dan titik $(-5,4)$ juga saya subtitusikan ke persamaan ini, saya dapat hasilnya ini persamaan 2. Dan ini juga seperti di atas, titik $(-13,-4)$ saya subtitusikan juga, hasilnya persamaan 3 .

PNM22091 : Tunggu dulu, tadikan kamu bilang kalau persamaan umumnya itu $(y-b)^{2}=$ $4 p(x-a)$, nah kenapa kamu bisa pakai persamaan umum itu?

WSM22092 : Karena parabolanya dia horizontal.

PNM22093 : Kenapa bisa?

WSM22094 : Kan soalnya dia diketahaui sumbu simetrinya sejajar dengan sumbu $\mathrm{x}=0$, jadi sumbu simetrrinya dia ada di sumbu-y, jadi parabolanya dia horizontal.

Hasil wawancara menunjukkan bahwa WS menjelaskan alasan mengapa menggunakan dan memilih prosedur tertentu yaitu menggunakan dan memilih persamaan umum parabola horizontal (WSM22092) dan (WSM22094) dalam menentukan persamaan parabola dari titik yang diketahui (WSM22064), sehingga dapat dikatakan bahwa WS mampu memberikan alasan menggunakan dan memilih persamaan umum parabola horizontal untuk mendapatkan persamaan parabola yang diminta.

Peneliti melakukan wawancara dengan WS untuk memperoleh informasi tentang kemampuan pemahaman konsep WS dalam menjelaskan kembali suatu objek-objek serta prosedur tertentu yang digunakan atau dimanfaatkan dengan menggunakan bahasa sendiri, sebagaimana transkrip berikut:

PNM22063 : Nah, bagaimana kamu menyelesaikannya?

WSM22064 : Persamaan umumnya $(y-b)^{2}=4 p(x-a)$, jadi ketiga titiknya ini saya subtitusikan satu-satu ke persamaan umum. Pertama titik $(-2,2)$ ini dulu saya subtitusikan kepersamaan umumnya ini. Dan saya dapat hasilnya persamaan 1, dan titik $(-5,4)$ juga saya subtitusikan ke persamaan ini, saya dapat hasilnya ini persamaan 2. Dan ini juga seperti diatas, titik $(-13,-4)$ saya subtitusikan juga, hasilnya persamaan 3 .

PNM22067 : Untuk apa kamu cari nilai $b, p$ dan $a$ ?

WSM22068 : Untuk persamaan parabolanya nanti. Kan saya pakai persamaan ini $(y-b)^{2}$ $=4 p(x-a)$, nah nanti saya ganti nilai $a, b$ dan $p$-nya.

PNM22069 : Terus, setelah kamu dapatkan 3 persamaan ini, kamu apakan lagi?

WSM22070 : Setelah itu, saya eliminasi persamaan satu dan persamaan dua. Saya dapat hasilnya $-12+4 b=12 p$ ini jadi persamaan 4 .

PNM22071 : Terus. 
WSM22072 : Saya eliminasi lagi persamaan 2 dan persamaan 3. Hasilnya $-16 b=32 p$.

PNM22075 : Ini, kenapa kamu ganti $b$ nya jadi negatif $2 \mathrm{p}$ ?

WSM22076 : Ini kak, saya subtitusi nilai $b$ nya dipersamaan 4 tadi, supaya saya dapatkan nilai $p$ nya

PNM22085 : Setelah itu?

WSM22086 : Setelah itu saya dapatkan sudah $a$ nya.

PNM22087 : Kalau sudah kamu dapatkan nilai $a$ nya, kenapa?

WSM22088 : Jadi, saya dapatkan sudah nilai $p, b$ sama $a$-nya. Nah dari sini saya ganti sudah $b, p$ sama $a$ nya yang dipersamaan umumnya ini.

Hasil wawancara menunjukkan bahwa WS menjelaskan kembali prosedur yang digunakan atau dimanfaatkan serta proses dalam memanfaatkan prosedur tersebut dan WS menjelaskan kembali langkah-langkah yang digunakan pada persamaan umum parabola horizontal tersebut dalam menentukan persamaan parabola, sehingga dapat dikatakan bahwa WS mampu memberikan alasan dan menjelaskan mengapa menggunakan dan memilih persamaan umum parabola horizontal.

\section{Pemahaman konsep matematika yang bergaya kongitif FD (DN) dalam menyelesaikan soal pada subpokok bahasan parabola}

Pemahaman konsep subjek DN dalam menyajikan masalah dalam berbagai bentuk representasi matematis dan menggunakan, memanfaatkan dan memilih prosedur tertentu dalam menentukan persamaan parabola, dipaparkan sebagaimana Gambar 4 dan 5:

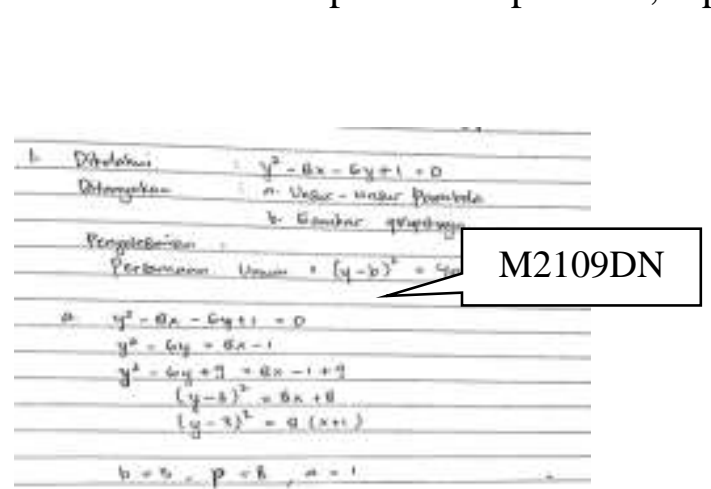

Gambar 4.

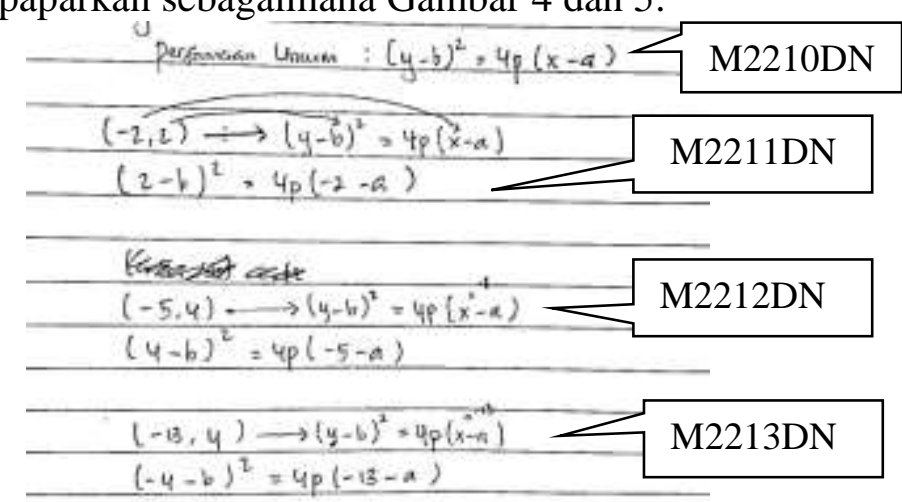

Gambar 5.

Berdasarkan Gambar 4, DN menyajikan persamaan parabola yang diketahui kedalam berbagai bentuk representasi matematis yaitu menyajikannya ke dalam bentuk persamaan umum parabola (M2209DN), sehingga dapat dikatakan bahwa DN mampu menyajikan masalah kedalam berbagai bentuk representasi matematis.

Peneliti melakukan wawancara dengan DN untuk memperoleh informasi lebih lanjut tentang pemahaman konsep matematika DN dalam menyajikan masalah kedalam berbagai bentuk representasi matematis sebagaimana transkrip berikut:

PNM21005 : Terus, bagaimana cara penyelesaianmu bagian $a$ nya ini?

DNM21006 : $y^{2}-8 x-6 y+1=0$. $-8 x$ dan 1 nya saya kasi pindah ruas. Jadi positif dia. $y^{2}-6 y=8 x-1$.

PNM21011 : Kamu mau kasi begini? Apa namanya kalau begini bentuknya?

DNM21012 : Saya faktorkan kak.

PNM21013 : Untuk apa kamu faktorkan?

DNM21014 : Supaya persamaan $y^{2}-8 x-6 y+1=0$ seperti persamaan umumnya. 
PNM21017 : Untuk apa kamu buat bentuknya seperti persamaan umumnya?

DNM21018 : Supaya dari sini, bisa saya dapat nilai $a, b$ sama $p$ nya.

Hasil wawancara menunjukkan bahwa FD menyajikan masalah kedalam berbagai bentuk representasi matematis (DNM21014) walaupun subjek DN belum mengetahui alasan mengapa menyajikan persamaan umum parabola sesuai yang dipaparkan (DNM21016).

Setelah merepresentasi matematis, DN dalam menggunakan, memanfaatkan dan memilih prosedur tertentu dalam menentukan persamaan parabola, dipaparkan sebagaimana Gambar. Berdasarkan Gambar 5, DN menggunakan, memanfaatkan dan memilih prosedur tertentu yaitu persamaan umum parabola (M2210DN) dalam menentukan persamaan parabola dari titik-titik yang diketahui yaitu (M2211DN), (M2212DN), dan (M2213DN).

Peneliti melakukan wawancara dengan DN untuk memperoleh informasi lebih lanjut tentang pemahaman konsep matematika DN dalam menggunakan, memanfaatkan dan memilih prosedur tertentu dalam menentukan persamaan parabola pada M2, yaitu sebagai berikut:

PNM22061 : Bagaimana caramu menyelesaikannya?

DNM22062 : Pertama saya anu kak,ini titik-titiknya saya apa namanya ini, saya subtitusi ke persamaan umumnya $(y-b)^{2}=4 p(x-a)$.

PNM22063 : Kenapa kamu pakai persamaan umum ini?

DNM22064 : Karena ini memang persamaan umumnya kak.

Hasil wawancara menunjukkan bahwa DN dapat menggunakan, memanfaatkan dan memilih prosedur tertentu yaitu persamaan umum parabola (DNM22062).Sehingga dapat dikatakan bahwa DN mampu menggunakan, memanfaatkan dan memilih prosedur tertentu dalam menentukan persamaan parabola.

Peneliti melakukan wawancara dengan DN untuk memperoleh informasi tentang kemampuan pemahaman konsep DN dalam menjelaskan kembali prosedur tertentu yang digunakan atau dimanfaatkan dengan menggunakan bahasa sendiri, sebagaimana transkrip berikut:

PNM22061 : Bagaimana caramu menyelesaikannya?

DNM22062 : Pertama saya anu kak,ini titik-titiknya saya apa namanya ini, saya subtitusi ke persamaan umumnya $(y-b)^{2}=4 p(x-a)$

PNM22063 : Kenapa kamu pakai persamaan umum ini?

DNM22064 : Karena ini memang persamaan umumnya kak.

PNM22069 : Tadi kamu bilang ketiga titik-titik yang diketahui kamu subtitusi ke persamaan umumnya, kenapa?

DNM22070 : Supaya saya dapat nilai $a, b$ sama $p$ nya.

PNM22071 : Apalagi yang kamu lakukan?

DNM22072 : Pertama titik $(-2,2)$, titik ini saya subtitusi. Setelah itu titik $(-5,4)$ ini lagi saya subtitusi ke persamaan umum. Terus begitu juga dengan titik $(-13,-4)$. Saya subtitusikan juga kepersamaan umum.

PNM22073 : Setelah itu, apa lagi yang kamu lakukan?

DNM22074 : Caranya hanya sampai sini saya ingat. Saya lupa kak.

PNM22075 : Saya lupa, kalau kamu sudah dapatkan nilai $a$, $b$ sama $p$ nya, kenapa?

DNM22076 : Kalau sudah saya dapatkan nilai $a, b$ sama $p$, saya ganti nilai $b, p$ dan $a$ nya ini persamaan umum.

PNM22077 : Untuk apa kamu ganti?

DNM22078 : Untuk saya dapatkan persamaan parabolanya 
Hasil wawancara menunjukkan bahwa DN menjelaskan kembali prosedur yang digunakan atau dimanfaatkan (DNM22062) serta DN menjelaskan kembali langkah-langkah yang digunakan pada persamaan umum sesuai yang dipaparkan dalam menentukan persamaan parabola (DNM22072, DNM22076 dan DNM22078), namun DN tidak dapat melanjutkan proses dalam memanfaatkan prosedur tersebut (DNM22074), sehingga dapat dikatakan bahwa DN mampu menjelaskan kembali prosedur yang digunakan dalam menentukan persamaan parabola.

\section{PEMBAHASAN}

Berdasarkan hasil analisis data hasil tes tertulis dan wawancara dalam menyelesaikan masalah pada subpokok bahasan parabola diperoleh profil pemahaman konsep matematika subjek WS yang bergaya kognitif Field Independent (FI) dan subjek DN yang bergaya kognitif Field Dependent (FD) berdasarkan indikator pemahaman konsep matematika yang digunakan yaitu dalam menyajikan suatu masalah, WS menuliskan halhal yang yang diketahui dan ditanyakan. Selanjutnya dalam mengklasifikasi unsur-unsur parabola, pengelompokkan unsur-unsur parabola yang dilakukan oleh WS yaitu dikelompokkan menurut bentuk parabolanya yang terdiri dari titik fokus, titik puncak, sumbu simetri, garis direktris dan panjang latus rectum yaitu parabola horizontal terbuka ke kanan. Sejalan hasil penelitian yang telah dilakukan Patria (2007) bahwa salah satu yang termuat dalam pemahaman konsep siswa yaitu mampu mengklasifikasikan objek-objek berdasarkan dipenuhi atau tidaknya persyaratan yang membentuk konsep itu.

Kemudian dalam memberi contoh dan non-contoh dari setiap unsur-unsur parabola, subjek WS menjelaskan setiap gambar yang diberikan merupakan contoh maupun noncontoh pada setiap unsur-unsur parabola yaitu titik puncak, titik fokus, garis direktris, sumbu simetri dan latus rectum, sehingga dapat dikatakan bahwa WS memahami setiap konsep pada unsur-unsur parabola. Hal ini sejalan dengan pernyataan Amir (2015) bahwa seorang siswa memiliki kemampuan dalam memahami suatu konsep matematika apabila ia telah mampu melakukan beberapa hal, salah satunya ialah memberi contoh dan bukan contoh atau ilustrasi yang berkaitan dengan suatu konsep guna memperjelas konsep itu.

Selanjutnya dalam menyajikan suatu masalah parabola dalam berbagai bentuk representasi matematis, hasil penyajian masalah subjek WS mengenai persamaan parabola yang diketahui yaitu dibentuk kedalam persamaan umum parabola yang digunakan guna mendapatkan nilai $a, b$ dan $p$, sehingga dapat dikatakan bahwa subjek WS memahami konsep dengan baik dalam menyajikan masalah persamaan parabola. Sejalan dengan hasil penelitian yang telah dilakukan oleh Patria (2007) bahwa salah satu yang termuat dalam pemahaman konsep yaitu mampu menyajikan situasi matematika kedalam berbagai cara serta mengetahui perbedaan, sehingga dapat dikatakan bahwa WS mampu menyajikan masalah keberbagai bentuk representasi matematis.

Kemudian dalam menggunakan, memanfaatkan dan memilih prosedur atau operasi tertentu dalam menentukan persamaan parabola, subjek WS menggunakan dan memilih persamaan umum parabola horizontal dalam menentukan persamaan parabola dari titik-titik yang diketahui. Sejalan dengan pernyataan Jaeng (2014) bahwa apabila pebelajar dapat mengklasifikasikan konstanta, variabel dan koefisien pada suatu persamaan serta dapat menggunakan rumus dalam menyelesaikan persamaan tersebut, maka kemampuan pebelajar sampai pada memahami konsep.

Setelah menggunakan, memanfaatkan dan memilih prosedur atau operasi tertentu dalam menentukan persamaan parabola, subjek WS menjelaskan kembali objek-objek, prosedur serta operasi tertentu yang digunakan atau dimanfaatkan dengan menggunakan 
bahasa sendiri yaitu subjek WS dalam menentukan persamaan parabola dari titik-titik yang diketahui menggunakan persamaan umum parabola horizontal. Subjek WS menjelaskan setiap langkah demi langkah yang ditempuh dalam menentukan persamaan parabola dengan menggunakan bahasanya sendiri, sehingga dapat dikatakan bahwa subjek WS mampu menjelaskan kembali objek-objek, prosedur serta operasi tertentu yang digunakan atau dimanfaatkan dengan menggunakan bahasanya sendiri. Sejalan dengan pernyataan Fatra (Mutmainna, 2018) bahwa seseorang dikatakan paham apabila ia dapat menjelaskan kembali apa yang dipahaminya dengan menggunakan bahasanya sendiri. Hal ini sejalan dengan pernyataan Darmono (2012) bahwa siswa yang bergaya kognitif Field Independent lebih efektif mereka belajar tahap demi tahap atau beraturan dimulai menganalisis fakta dan memproses untuk mendapatkan. Berdasarkan hal tersebut WS dapat dikatakan telah memahami konsep matematika dalam menyelesaikan soal pada subpokok bahasan parabola. Hal ini menunjukkan bahwa pentingnya pemahaman konsep dalam menyelesaikan suatu permasalahan matematika. Hal ini sejalan dengan pendapat Kesumawati (2008) dalam proses pembelajaran matematika, pemahaman konsep merupakan bagian yang sangat penting.

Subjek DN dalam menyajikan suatu masalah, yaitu DN menuliskan hal-hal yang yang diketahui dan ditanyakan. Selanjutnya dalam menyajikan suatu masalah persamaan parabola dalam berbagai bentuk representasi matematis, subjek DN menuliskan hal yang diketahui dan menyajikan persamaan parabola yang diketahui kedalam bentuk persamaan umum parabola guna mendapatkan nilai $a, b$ dan $p$, namun DN kurang teliti dalam menentukan nilai $p$, sehingga nilai $p$ yang didapatkan DN kurang tepat. Sejalan dengan hasil penelitian yang telah dilakukan oleh Saja'ah (2018) bahwa kurangya ketelitian dan kehati-haitan dalam melakukan operasi hitung sehingga siswa masih salah dalam menjalankan dan menjawab soal, akan tetapi walaupun nilai $p$ yang didapatkan DN kurang tepat, DN dapat dikatakan mampu menyajikan masalah ke dalam berbagai bentuk representasi matematis. Sejalan dengan pernyataan Jaeng (2014) bahwa apabila pebelajar dapat mengklasifikasikan konstanta, variabel dan koefisien pada suatu persamaan serta dapat menggunakan rumus dalam menyelesaikan persamaan tersebut, maka kemampuan pebelajar sampai pada memahami konsep.

Dalam menggunakan, memanfaatkan dan memilih prosedur serta operasi tertentu dalam menentukan persamaan parabola, subjek DN menggunakan persamaan umum parabola walaupun subjek DN tidak mengetahui jenis persamaan umum parabola yang digunakan. Kemudian subjek DN menjelaskan kembali prosedur atau operasi tertentu yang digunakan atau dimanfaatkan dengan menggunakan bahasa sendiri yaitu subjek DN menjelaskan kembali persamaan umum parabola yang digunakan dalam menentukan persamaan parabola dari titiktitik yang diketahui walaupun dalam proses penyelesaiannya subjek DN belum memahami dengan baik langkah-langkah yang harus digunakan sehingga DN tidak mendapatkan hasil yang diminta, akan tetapi DN mampu menjelaskan kembali dengan menggunakan bahasanya sendiri. Sejalan dengan pernyataan Fatra (Mutmainna, 2018) bahwa seseorang dikatakan paham apabila ia dapat menjelaskan kembali apa yang dipahaminya dengan menggunakan bahasanya sendiri.

Subjek DN dalam mengklasifikasikan unsur-unsur parabola kurang tepat karena subjek DN kurang memahami setiap unsur-unsur dalam parabola. Selanjutnya dalam memberi contoh dan non-contoh pada setiap unsur-unsur parabola, subjek DN hanya bisa memberi contoh pada garis direktris dan titik puncak. Subjek DN tidak dapat memberi contoh dan non-contoh mengenai sumbu simetri, titik puncak dan latus rectum karena 
subjek DN kurang memahami hal tersebut sehingga DN dikatakan tidak dapat memberi contoh dan non-contoh pada setiap unsur-unsur parabola.

Sejalan dengan pernyataan Darmono (2012) bahwa siswa yang bergaya kognitif Filed Dependent mengalami kesulitan dalam memecahkan masalah sendiri. Hal ini menunjukkan bahwa pentingnya pemahaman konsep dalam menyelesaikan suatu permasalahan matematika. Hal ini sejalan dengan pendapat Kesumawati (2008) dalam proses pembelajaran matematika, pemahaman konsep merupakan bagian yang sangat penting.

\section{KESIMPULAN}

Profil pemahaman konsep matematika siswa WS yang bergaya kognitif Field Independent (FI) dalam menyelesaikan soal parabola yaitu WS menuliskan hal-hal yang yang diketahui dan ditanyakan. Selanjutnya dalam mengklasifikasi unsur-unsur parabola, subjek WS mengelompokkan unsur-unsur parabola menurut bentuk parabolanya yang terdiri dari titik fokus, titik puncak, sumbu simetri, garis direktris dan panjang latus rectum yaitu parabola horizontal terbuka ke kanan. Selanjutnya dalam memberi contoh dan noncontoh pada setiap unsur-unsur parabola, subjek WS menjelaskan setiap gambar yang diberikan merupakan contoh maupun non-contoh pada setiap unsur-unsur parabola. Dalam menyajikan suatu masalah parabola dalam berbagai bentuk representasi matematis, WS menyajikan persamaan parabola yang diketahui kedalam bentuk persamaan umum parabola yang digunakan guna mendapatkan nilai $a, b$ dan $p$. Kemudian dalam menggunakan, memanfaatkan dan memilih prosedur atau operasi tertentu dalam menentukan persamaan parabola, subjek WS menggunakan dan memilih persamaan umum parabola horizontal dalam menentukan persamaan parabola dari titik-titik yang diketahui. Setelah menggunakan, memanfaatkan dan memilih prosedur atau operasi tertentu dalam menentukan persamaan parabola, subjek WS menjelaskan kembali objek-objek, prosedur serta operasi tertentu yang digunakan atau dimanfaatkan dengan menggunakan bahasa sendiri yaitu subjek WS dalam menentukan persamaan parabola menggunakan persamaan umum parabola horizontal serta subjek WS menjelaskan setiap langkah demi langkah yang ditempuh dalam menentukan persamaan parabola dengan menggunakan bahasanya sendiri.

Kemudian profil pemahaman konsep matematika siswa DN yang bergaya kognitif Field Dependent (FD) dalam menyelesaikan soal parabola yaitu DN menuliskan hal-hal yang yang diketahui dan ditanyakan. Selanjutnya DN menyajikan suatu masalah persamaan parabola dalam berbagai bentuk representasi matematis. DN menyajikan persamaan parabola yang diketahui kedalam bentuk persamaan umum parabola guna mendapatkan nilai $a, b$ dan $p$, namun DN kurang teliti dalam menentukan nilai $p$, sehingga nilai $p$ yang didapatkan $\mathrm{DN}$ kurang tepat. Dalam menggunakan, memanfaatkan dan memilih prosedur serta operasi tertentu dalam menentukan persamaan parabola, subjek DN menggunakan persamaan umum parabola walaupun subjek DN tidak mengetahui jenis persamaan umum parabola yang digunakan. Kemudian subjek DN menjelaskan kembali prosedur atau operasi tertentu yang digunakan atau dimanfaatkan dengan menggunakan bahasa sendiri yaitu subjek DN menjelaskan kembali persamaan umum parabola yang digunakan dalam menentukan persamaan parabola dari titik-titik yang diketahui walaupun dalam proses penyelesaiannya subjek DN belum memahami dengan baik langkah-langkah yang harus digunakan sehingga DN tidak mendapatkan hasil yang diminta, akan tetapi DN mampu menjelaskan kembali dengan menggunakan bahasanya sendiri. 
Selama proses penyelesaian masalah, kedua subjek menuliskan yang diketahui dan ditanyakan dari soal. Adapun persamaan dan perbedaan pemahaman konsep matematika keduanya yaitu dalam menyajikan masalah kedalam berbagai bentuk representasi matematis, keduanya sama-sama menyajikan masalah kedalam bentuk persamaan parabola, perbedaan dari keduanya yaitu alasan subjek WS dan subjek DN berbeda dalam merepresentasi matematis. Kemudian dalam menggunakan dan memilih prosedur tertentu hingga menjelaskannya kembali dengan menggunakan bahasanya sendiri, keduanya menggunakan persamaan umum yang sama, akan tetapi penjelasan subjek WS dengan menggunakan bahasanya sendiri berbeda dengan penjelasan subjek DN. Subjek WS menjelaskan secara detail prosedur yang ia gunakan, dari penggunaan persamaan umum, langkah-langkah yang ia tempuh sampai mendapatkan hasil yang diminta, sedangkan subjek DN menjelaskan prosedur yang ia gunakan, tetapi pada saat menjelaskan langkah-langkah yang ia tempuh sampai mendapatkan hasil yang diminta, subjek DN mengalami kesulitan di langkah tersebut, katanya ada beberapa langkah yang ia lupa, sehingga menyebabkan DN tidak dapat meneruskan cara kerjanya sampai mendapatkan hasil yang diminta, tetapi subjek DN mampu menjelaskan kembali langkah akhir yang akan ditempuhnya.

\section{SARAN}

Berdasarkan kesimpulan dan hasil penelitian ini hendaknya dalam mengajar matematika, guru maupun calon guru pada saat melaksanakan pembelajaran perlu memperhatikan gaya kognitif yang dimiliki siswa baik Field Independent (FI) maupun Field Dependent (FD) karena sangat mempengaruhi pemahaman konsep matematika siswa. Perhatian guru terhadap siswa yang memiliki gaya kognitif Field Independent (FI) dan Field Dependent (FD) tentunya akan berimplikasi pada pemilihan strategi pembelajaran yang sesuai sehingga dapat membantu pemahaman konsep matematika siswa.

\section{DAFTAR PUSTAKA}

Amir, A (2015). Pemahaman konsep dan pemecahan masalah dalam pembelajaran matematika.Jurnal.Kependidikan dan sains.[Online]. Tersedia: http://repo.iainpadangsidimpuan.ac.id/142/. [25 Maret 2019]

Darmono, A. (2012). identifikasi gaya kognitif (cognitive style) peserta didik dalam belajar. Jurnal.Sekolah Tinggi Agama Islama (STAI) Ngawi.[Online]. Tersedia: https://media.neliti.com/media/publications/76589-ID-gaya-kognitif. [ 24 Januari 2019]

Darojah, D. M \& Suparman (2018). Analisis kebutuhan desain pembelajaran irisan kerucut menggunakan pendekatan PMRI. Prosiding Seminar Nasional Matematika Dan Pendidikan Metematikan Universitas Muhamaiyah Purworejo. [online]. Tersedia: . [11 Januari 2019].

Devi, M. P. (2018). Pemahaman konsep persamaan garis lurus ditinjau dari gaya kognitif kelas VIII. Skripsi. Program Studi Pendidikan Matematika. FKIP. Universitas Muhammadiyah Surakarta. [online]. Tersedia:eprints.i=ums.ac.id/64468/1/naskah $\% 20$ publikasi.pdf. [4 Januari 2019].

Kesumawati, M. (2008). Peningkatan kemampuan pemahaman, pemecahan masalah dan disposisi matematis siswa SMP melalui pendekatan pendidikan matematika 
150 AKSIOMA, Volume 8 Nomor 2, September 2019

realistic. Thesis.Universitas Indonesia. [Online]. Tersedia: http://repository.upi.edu 17975/. [25 Maret 2019]

Kumalasari, A. \& Putri, R. O. P. E. (2013).Kesulitan belajar matematika siswa ditinjau dari segi kemampuan koneksi matematika.Prosiding seminar nasional matematika dan pendidikan matematika. Universitas negeri Yogyakarta. [online]. Tersedia:https: //eprints.uny.ac.id/10725/1/P\%20-\%202.pdf .[ 20 Desember 2018].

Jaeng, M. (2014).Teori belajar dan inovasi matematika. Program Studi Pendidikan Matematika. FKIP. Universitas Tadulako.

Mutmainna, D. Mania, S. A, S. (2018). Pengembangan instrumen tes diagnostik pilihan ganda dua tingkat untuk mengidentifikasi pemahaman konsep matematika. Jurnal Matematika dan Pembelajaran UIN Alauddin. Tersedia: https://www.researchgate. net/public ation/32626. [ 4 Mei 2019].

Nurfarikhin, F. (2010).Hubungan kemampuan pemahaman konsep dan kemampuan penalaran dengan kemampuan Pemecahan masalah pada materi bangun ruang sisi lengkung peserta didik kelas IX MTs NU 24 Darul Ulum Pidodo Kulon Patebon Kendal.Skripsi.IAIN Walisongo Semarang. [Online]. Tersedia: eprints. Walisongo.ac.id./4873/1/63511031.[ 30 November 2018]

Saja'ah, U.V. (2018). Analisis kesulitan siswa kelas iv sekolah dasar dalam menyelesaikan soal pemecahan masalah. Jurnal Pendidikan Dasar UPI.

Tersedia:https://www.google.c om /url ?sa=t\&rct=j\&q=\&esrc=uact=8\&ved [4 Mei 2019].

Sari, P. P. (2015). Analisis kasus rendahnya prestasi belajar matematika siswa pada materi irisan kerucut dan solusi pemecahannya di kelas XI MIA 2 SMA IT HIDAYAH.Prosiding. Pascasarjana Universitas Sebelas Maret.Diterbitkan. [online]. Tersedia:https://www.google.com/url?sa=t\&rct=j\&q1. [24 November 2018].

Sugiyono. (2015). Metode penelitian kombinasi (mixed Methods). Bandung: Alfabeta.

Suryosubroto, B. (2009). Proses belajar mengajar di sekolah. Jakarta: Rineka Cipta.

Utari, V. (2012).Peningkatan kemampuan pemahaman konsep melalui pendekatan PMR dalam pokok bahasan prisma dan limas.Jurnal Pendidikan Matematika FMIPA UNP. [online]. Tersedia:ejournal.unp.ac.id /students/index.php. [11 Januari 2019].

Patria, 2007. Pemahaman konsep. Tersedia https://www.scribd.com/document/273044914/ Pemahaman-Konsep. [ 4 Mei 2019].

Witkin, H.A., C.A. Moore, D.R. Goodenough, \& P.W. Cox. (1975). Field-Dependent and Field-Independent Cognitive Style and Their Educational Implications. Review of Reaserch, 47(1): 1-64. [20 November 2018]. 